\title{
The "VEIL" Surrounding Alexander Henry, the Elder's Mixed-Blood Sons
}

\author{
Anatol L. Scott
}

ABSTRACT: Fur traders have played an inordinately important role in western Canadian history; their records and their published journals are the bedrock of our historiography. Paradoxically, we know little about the private lives of many of these traders. By assembling a readily available and conflicting body of knowledge on Alexander Henry, the Elder, and by linking it to ocher scattered bits of information, this paper presents a profile of Henry and his family that differs considerably from the traditionally accepted view.

Alexander Henry, the Elder's Travels and Adventures in Canada was one of the few sources from which early historians could glean information about conditions faced by English-speaking fur traders who penetrated the Great Lakes region shortly after the Conquest of New France and about experiences of some western Ojibway and Saulteaux communities during the transition from a French to an English colonial regime.' The prominent place of Travels in Western Canadian historiography stemmed from the lack of other information at the time historians began reconstructing these early experiences. But since then, a growing body of historians, anthropologists, and echnologists have provided a much broader view of this period than even the most knowledgeable participants in the early fur trade would have had.

Today some scholars acknowledge that many of these early works contained Eurocentric biases which contributed to the distorted images many earlier historians had on interactions between European and aboriginal peoples. ${ }^{2}$ They argue that such works were travel literature, written to serve the needs of an imperial culture and, therefore, uncritical accepcance of them as the cornerstone of western Canadian historiography poses a continuing danger to our underscanding of that time. Ian MacLaren has issued a warning to historians who consult such travel literature: 
a sharp focus must be directed onto the writer. That focus must investigate such customary reading practices as those that equate the explorer/traveller with the author, and published observations with exact representations of reality as it was experienced ... [It] involves recognizing the cultural role played for imperial cultures by wilderness travellers, few of whom, at least before this century in Canada, were writers first and foremost. ${ }^{3}$

As one of these travellers, Henry deserves direct and penetrating study, but almost nothing is known about him. Whereas earlier historians relied heavily on information provided by James Bain, editor of the 1901 edition of Travels, later historians added scattered bits and pieces of evidence recorded by other fur traders and friends to arrive at a laudatory historical representation of him.

Besides having been one of the more interesting recorders of the events at Fort Michilimackinac during Pontiac's uprising, Alexander Henry is remembered for his accomplishments in business and society. He was one of the important business leaders who turned Montreal into the innovative centre of business expansion and of the fur trade and, he was a founding member of Montreal's Beaver Club. The consensus on other aspects of Henry's life needs to be questioned, however, since contradictory evidence makes it unclear whether Henry was the author of the published version of Travels; whether he was the father of three, four, or five children; whether Julia Kittson, his wife, was the mother of all these children and; hence, whether some were the product of an earlier country marriage (or marriages).

There have been attempts to overcome these uncertainties. In criticizing Henry's depiction of Charles de Langlade in Travels, Joseph Tassé became the first to question the truthfulness and accuracy of Alexander Henry's writings. ${ }^{4}$ In 1912 John Thomas Lee argued that "it needs but a modicum of critical faculty to discern that Henry never penned the work bearing his name." The issue was not settled, however, and Henry's inconsistent representation of Wawatam, the person who saved his life during Pontiac's uprising, later became a consideration of novelist Henry 
Bedford-Jones who also doubted the veracity of Henry's tales in that "his relations with Wawatam, who never existed in fact, were meant to serve as an embellishment of the tale." Thus, by the 1930s scholars generally knew that Henry's work was not a very reliable historical source. Still, well-known historian, Francis Parkman, had joined Milo Quaife in defending Henry against Bedford-Jones's attack, and Travels remained a familiar, although carefully used, source for historians.

By the 1930s genealogists such as Adelaide Storrs and Freda Waldon had begun to investigate Henry's background. Information Waldon uncovered during her investigation convinced her to explore the probability that Henry had a previous marriage to a woman other than Julia Kittson but she concluded that there was no evidence to support such a conjecture. ${ }^{7}$ Based on confusing details in Henry's letters, however, Waldon suggested that he had three sons instead of two. The works of these genealogists seem to have been ignored by historians and David Armour did not refer to them in his 1987 Dictionary of Canadian Biography $(D C B)$ article on Alexander Henry. ${ }^{8}$ Armour suggested that the Elder Henry was "possibly the third son of Alexander Henry, a merchant of New Brunswick, NJ, and Elizabeth -." A year later, having consulted the genealogical findings, Barry Gough contradicted Armour, indicating that John Henry, Alexander and Elizabeth's eldest son, was the Elder Henry's father. ${ }^{10}$

These issues have not been resolved. Although bits of information from various sources have not provided definitive answers, they imply that an almost impenetrable veil surrounds Alexander Henry. A look behind that veil further suggests that certain people may have taken purposeful actions to shroud the real man. As a result, historians may have been blinded; their knowledge of Henry may have been obscured, thus causing his life to seem more idyllic than it was.

The most widely used version of Travels, James Bain's 1901 edition, appears to be the source of many discrepancies. For example Bain asserts that, after his journeys to the 
Indian country, in 1781 Henry married and settled down to enjoy his "financial competency in the bosom of his family and amidst a circle of highly respectable friends."1 Armour corrected Bain's overstatement when he suggested that, after 1785, Henry suffered a series of financial setbacks. ${ }^{12}$ A critical examination of Henry's financial competency, however, suggests that, for most of his years in Montreal, his financial situation was not as comfortable as even Armour suggested. ${ }^{13}$ Questions regarding Henry's financial circumstances lead to questions regarding the bosom of his family. ${ }^{14}$ Since Henry's Travels gives no information on his family, one must use other sources. Freda Waldon's 1930 MA thesis is the only investigation of Henry's family. She uncovered a memorandum written by Norman William Bethune, third son of Norman Bethune, an important member of the Henry household. ${ }^{15}$ This document provided information on Julia Kittson and her family. From it, we learn that

our great-grandfather Kittson was born in Dublin, where I have been told the name may still be met with. He was in the army, but in what rank or branch of the service I am unable to say. He must have seen several campaigns in America as his wife is said to have crossed the Atlantic several times endeavoring to rejoin her husband but passing him each time in mid-ocean. Finally he sailed with Wolfe's expedition against Louisbourg and Quebec and must have fallen in battle or died from disease or hardship during that campaign, for on our Great-grandmother's arrival at Quebec on board the relieving squadron in the spring of 1760 she found herself a widow. As far as I can gather she was born in the town of NewtonLimavody, Ireland. I am inclined to think her maiden name was Sawer or Sawyer. In her various trips across the ocean she had always taken with her certain "ventures" in goods, either way, a common practice in those days and had acquired quite a little money. She, therefore, decided to remain in Canada, where she subsequently married Alexander Henry, the noted fur-trader and traveller in the Northwest. By her first husband she had one son, our grandfather George Kitson. By her marriage with Mr. Henry she had two sons, Alexander and William and a daughter Julia. ${ }^{16}$ 
Bethune's memorandum suggests that Julia Kittson was a woman of considerable personal fortitude. Even before the death of her first husband, John George Kittson, she was undercaking the risks associated with transatlantic journeys in pursuit of her own business endeavours. It appears that, after her husband's deach, these ventures permitted her to raise a young son alone, in a society where there was little opportunity for women to provide independently for themselves. It would appear that she was successful as her son, George Kittson, was held in sufficient esteem to marry "Anne Tucker of Sorel, daughter of a U.E. Loyalist who had been granted lands in the vicinity of that village."17

Waldon also revealed the existence of conflicting stories, both of which came from the Bethune family. The first held that "Mrs. Kittson was Alexander Henry's second wife and not the mother of his children"; the other, that "Mrs. John George Kittson was the only wife of Alexander Henry and the mother of his children." 18 This contradiction led Waldon to investigate Henry's family history. After conducting many interviews and having examined the Bethune memorandum, Waldon concluded that the evidence supporting Julia Kittson having mothered all of the Henry children "seems conclusive. The Bethunes are emphatic on this point." It is noteworthy that Waldon did not write "is," but "seems," conclusive, and that, by adding the sentence "The Bethunes are emphatic on this point," she gave the impression, perhaps intentionally, that she had lingering doubts. ${ }^{19}$

Waldon seems to have assumed that Henry's children had to be the result of a marriage, either to Julia Kittson or to another European woman. Since no former European Mrs. Henry was found and, perhaps because of a 1930 s bias that may have discounted the possibility of a non-European wife, Waldon accepted the words recorded in the Bethune memorandum and concluded that Henry's three children, Alexander, William, and Julia, sprang from the only known marriage. Despite arguing for the existence of one other son, Waldon did not pursue the possibility that Henry may have had children resulting from relationships with non- 
European women. Research conducted since Waldon's thesis was written shows that country marriages were a necessary and acceptable aspect of the fur trade. Since Henry stayed in the Indian country for an extended time, and since "manly beauty is the same among all nations," it is possible that Henry contracted a country marriage. ${ }^{20}$

Other commentators have speculated that Henry had children by a country marriage before he met and married Julia Kittson. In 1838, Mrs. Anna Jameson remarked that "I can find no type of the women as Henry does not tell us his adventures among the squaws, but no doubt he might have found both Calypsos and Nausicaas, and even a Penelope, among them."21 In an 1893 novel, Mary Hartwell Catherwood created a French girl, Marie, whom she linked romantically to Henry, not in Montreal, but in the Indian country. ${ }^{22}$ According to a letter written by Norman Bethune in 1822, Henry did have a servant named Mary but, it is unlikely that Catherwood knew of this letter, which only became public in Waldon's 1930 thesis. ${ }^{23}$ It is possible, however, that Catherwood, when she was writing her book, was aware of a continuing suspicion, based perhaps on rumour, concerning Henry and Mary, his servant. Even Marjorie Campbell, perhaps unaware of Waldon's thesis, made the partially erroneous statement that "Alexander Henry and James McGill were about to marry pretry daughters of their Canadien associates." ${ }^{24}$ The recurring suggestion that Henry had earlier relationships with Indian women and the lack of information on Julia Kittson and how she came to be married to Alexander Henry seem to have led to some speculation.

Linked to these uncertainties is the question of why Henry wrote about one other son who was unknown to historians and, why it is that this son seems just as unknown to Norman William Bethune who should have received information directly from his parents, from the members of George Kittson's large household, and from Julia Kittson who died in his father's home. ${ }^{25}$ Norman William Bethune was too close to the Henry family nor to have known of other sons. As the author of the memorandum which 
recorded the scant information we have on Henry's wife and children, and which defeated all of Waldon's attempts to uncover the circumstances surrounding Henry's marriage and family, Bethune's failure to mention other children casts doubts on the validity of his memorandum and throws light on Waldon's implied doubt.

Until the publication of David Armour's article, all historians except Waldon agreed that Henry had two sons and a daughter and that William was older than Alexander. Contradicting Waldon and the general consensus, Armour states that "On 11 June 1785 he married a widow, Julia Ketson. Their eldest child, Julia, had been born in October 1780. Four sons, Alexander, William, Robert, and John, were born between 1782 and $1786 .{ }^{26}$ This information is significant for several reasons. First, Armour asserts that Julia was the oldest. Second, he declares that Alexander, not William, was the oldest son, thus partially confirming the order of birth suggested by the Bethune memorandum. Third, Armour claims that there were two other sons, Robert and John, who were unknown to the historical record and to Norman William Bethune. These suggestions differ significantly from the previously accepted Henry genealogy and they undermine the accuracy of the Bethune memorandum. ${ }^{27}$

Armour's mention of the sons and their order of birth are based on the baptismal records of Christ Church (Anglican), Montreal, held at the Archives Nationales du Québec. ${ }^{28}$ Bain had earlier thought a Robert Henry who had lived in the Henry household for a time was an adopted nephew, but Alexander Henry, the Younger's will shows Robert Henry to have been the younger brother of Alexander Henry, the Younger. ${ }^{29}$ Because it was based on verifiable primary sources, Armour's biography of Henry properly supports the consensus that Julia Kittson was the mother of Henry's children. When Julia married Henry, however, she must have been approaching menopause. ${ }^{30}$ As Waldon suggests more succinctly, "Mrs. Kittson must have been a very young widow in 1760 to have had three children after 1783." "31 Armour's evidence, therefore, casts even deeper 
doubt for he discovered one more child than Waldon had. Given her age, it is doubtful that Julia Kittson could have been the mother of all five Henry children.

Perhaps Henry's original biographer wished to but could not express these doubts ${ }^{32}$ and Armour's claim that the Henrys were married in 1785 (not 1781) proves that Henry's biographer had good reasons to be concerned; he likely knew or suspected that all except the last of the Henry children, John, were illegitimate. If Henry and Julia were not legally married at the time their children were born, given the social stigma which then existed among elites against such relationships, they probably would have been excluded from the social elite of Montreal. But the historical record suggests that Henry was very much a part of that elite. If so, social ostracism could have been avoided only if the elite had accepted that Henry and Julia were legally married, and this could have been accomplished only if, at some point after 1776, Julia was introduced to them as Henry's lawful wife.

While consideration should be given to the probability that Julia arrived in Montreal about 1760, the main sources in support of her presence there before 1776 are Bain and the Bethune memorandum, both of which are shrouded in considerable doubt as a result of the work of Waldon and Armour. Julia and Henry could not have met before 1776 since, according to his Travels, he was never in Montreal berween 1760 and 1776. Immediately after leaving the Indian country, from autumn 1776 to spring 1777, Henry made his first trip to Europe. During fall 1778 to spring 1779, he again visited Europe. At some time between 1780 and 1781 , the period of his third trip to Europe, Henry and Julia were accepted as a married couple by the Montreal community. Because they were not publicly married in Montreal between 1779 and 1780 , the leading community members may have assumed or may have been led to believe that, during that interval, they had been married elsewhere. The assumption of marriage seems to have become generally accepted and Bain, who relied heavily on the biographies which were published in the Canadian Magazine 
and the Montreal Gazette at the time of Henry's death, ignored the biographer's doubts and brought that generalization into the historiography when he implied that the Henrys were married about 1781 . No source shows Julia to have been in Montreal from 1760 to 1779 . Therefore, the possibility that Julia may have arrived there at the end of Henry's second trip to Europe should be considered.

Perhaps on his 1776 trip to England, Henry went to Dublin to visit Scotch-I rish relatives and met Julia Kittson there. ${ }^{33}$ Although no information has yet been found to support this conjecture, it is relevant when one reconsiders, given the above uncertainties, Norman Bethune's dubious explanation for Julia's presence in Montreal:

on our Great-grandmother's arrival at Quebec on board the relieving squadron in the spring of 1760 she found herself a widow ... In her various trips across the ocean she had always taken with her certain "ventures" in goods, either way, a common practice in those days and had acquired quite a little money. She, therefore, decided to remain in Canada, where she subsequently married Alexander Henry.

It was common practice for men such as Alexander Henry to undertake transadlantic ventures in goods during those years but, given the strictures surrounding women, it is very unlikely that a woman as young as Julia could have undertaken such business endeavours alone.

Although there are substantiated explanations for Henry's first and third trips to Europe, there is no clear reason for his second trip. Henry may well have taken the 1778-9 trip to pursue negotiations with the Hudson's Bay Company. However, if Henry had met Julia in Dublin and had become smitten with her during his first trip, besides his business interest, he would have had a very personal reason to make that second trip. There is no exact information on when Henry returned to Montreal from that second trip but, given the added incentive of an involvement with Julia and in the absence of evidence to the contrary, it is possible that he did not return there until the spring of $1780 .{ }^{34}$ 
Because their daughter, Julia, was born on 22 October 1780 , by late spring 1780 Henry and Julia could have been faced with the predicament of Julia's unwedded pregnancy. To avoid social ostracism, Henry may have had little choice but to present Julia as his wife. If this is so, the Henrys' 1785 marriage should have been a very private affair. Their late marriage was, in fact, arranged by licence and seems not to have been publicly celebrated or generally known. ${ }^{35}$ These coincidences combine to suggest that Bethune's narrative pertaining to the meeting of Alexander Henry and Julia Kittson may have been an attempt to shroud the embarrassing circumstances behind the Henrys' marriage. These accumulating uncercainties lead one to pursue other questions, specifically the question of how many children the Henrys may have had.

Certain parts of the genealogical record can be accepted without much need for further investigation. ${ }^{36}$ Based on the seemingly consistent tendency of naming children after other members of the Henry family, for example, we may safely assume that, since the name Julia does not appear in the earlier Henry family tree, his daughter was named after her biological mother, Julia Kittson. ${ }^{37}$ Further, in his 27 August 1813 letter to Askin, Henry records, referring to his son, Alexander, that "Mr. McGillavray [sic] is arrived from Grand Portage and brings me the unfortunate account of one of my sons being killed on McKinzeys' [sic] River by the Indians, with all his men-this is a wound at my time of life that affects me and his poor Mother very much. ${ }^{38}$ Thus, it appears that both Julia and Alexander were the Henrys' biological children.

Henry, however, was not as clear in his references to his other children. In the same letter, he wrote: "I have one son at Sea a midshipman which [sic] $I$ have not heard of for upwards of two years. I think he must be dead-the only one remaining in the N. West gone to the South Sea. you will see $I$ have been unforcunate in my sons." ${ }^{39}$ Henry's use of the word " $\mathrm{I}$ " when writing about these sons suggests that they may not have been Julia's sons. ${ }^{40}$ Furthermore, and as Waldon noted, Henry's letter seems to refer to a hitherto 
unknown son. His reference to a son "remaining in the $\mathrm{N}$. West gone to the South Sea," is apparently to William, who was then, "in charge of a post on the Willamette River." He could not be referring to Alexander because Alexander was dead. Apparently, then Norman William Bethune did not know of at least one of Henry's sons.

A letter to Askin dated 9 May 1815 partially clarifies how many sons Henry had. Henry wrote that "I have only one son Daughter \& one son living [sic] one was killed in the North West the other died in the West Indies, being a midshipman in the navy." 42 Henry's suspicion, of two years earlier, that his son, the midshipman, had been killed in the West Indies, had clearly been confirmed. The quoted sentence also reiterates that Alexander had been killed in the North West. If Henry had three sons, this letter confirms that the son remaining alive was William. However, after identifying three sons, we are left with the confusing remarks that he still had "only one son Daughter and one son living." Punctuated and written properly, the sentence would read that he had "only one son, [a] daughter, and one [other] son living." 43 In other words, he had two sons and a daughter remaining alive. If we continue to assume that his reference to the son "gone to the South Sea" is to William, we are confronted with a fourch, unnamed son, still alive. Of this son Bethune also knew nothing.

Henry's letters suggest, therefore, that there were two sons besides Alexander and William. Armour offers three possible names: Charles, Robert, and John. An attempt at clarification is, therefore, required and it is in this area that Gough's concept of interlocking naming relationships has proven to be extremely enlightening. Appendix I indicates that the Elder's grandfather was named Alexander. Since we have no accepted record of preceding generations of Henrys, it may be supposed that the grandfather named his first son after his father (the son's grandfather), John. In turn, the first son, John, the Elder's father, named his first son (the Elder) after the son's grandfather, Alexander. John Henry's second son was named John, after the son's father. William, the next child, was named after an uncle. 
There seems, then, to have been a naming pattern used by earlier Henrys: the first son was to be named after the grandfather, the next after the father and, others after uncles of choice. This hypothesis is supported by the names which the Elder's younger brother, John, gave to his children. ${ }^{44}$ John's first son, John, was named after the son's grandfather. But, because the father's name was also John, the next son, Alexander Henry, The Younger, was named after an uncle, in this case, Alexander Henry, the Elder. The practice was continued by Alexander Henry, the Younger but, during his day it was modified to fit what may have been an emerging trend, the practice of adding a middle name. The Younger's first son, who was mixedblood, was given two names, John Alexander; John, in honour of the son's grandfather and, Alexander, in honour of the son's father. 45

Based on the foregoing, it is being asserted that an adaptable naming pattern was followed by generations of the Henry family. Therefore, if the elder Henry had four sons (as this paper as well as Armour have suggested), the first would have been named John (in honour of the son's grandfather), the second named Alexander (in honour of the son's father), the third William (in honour of the father's second brother), and the fourth James or Robert (in honour of one of the father's uncles, assuming that the fifth son of Alexander and Elizabeth Henry was named Robert). Given the strength of tradition which applied then, the naming pattern makes it unlikely that Alexander Henry would have named one of his four sons Charles. With the exception of that name, the names which Armour suggested for the children are likely to be the names Henry would have chosen for his sons.

However, Armour's suggested birth order does not conform to the pattern which seems to have been an established part of the naming tradition, and the many doubts surrounding the information on the Henry family suggest that one cannot blindly accept any documents pertaining to Henry. If the documents Armour relied on are considered suspicious and if the general consensus could 
be proven correct that William was older than Alexander, we are faced with the problem of explaining how the documented evidence could have been corrupted. Indeed, if the documented evidence is incorrect, the information contained in those documents may have been put there for specific reasons. Such a conjecture is allowable because some Henry children seem to have been removed from the family record and because of the uncertainty over whether William or Alexander was the oldest son. ${ }^{46}$

Perhaps it is because some of his children were mixed blood. Evidence supporting such a theory is contained in the two letters discussed above in which Henry did not link Julia directly to William and one other unnamed son. ${ }^{47}$ In the first letter, he acknowledged being their father, but Julia may not have been the mother. The second letter offers partial clarification even as it introduces other complications. The problematic " $\&$ one son," placed behind the "only one son Daughter," is unlikely to be the result of senility because evidence of it is not revealed elsewhere in his letters. Nor is it a "false start" to a new sentence, especially given that the next portion of the sentence begins with "one." 48 The " $\&$ " so conspicuously placed before the "one son" may carry a message that Henry intended to convey to Askin: there was something different about the one son he strategically separated from the "only one son Daughter." Henry's phraseology may reflect a code that existed among those who were involved in country marriages or who had sired illegitimate children. Because of his own experience with children born out of legal wedlock, Askin would have understood the coded reference. ${ }^{99}$ This would mean that, of the two sons still alive, one was a child of Julia Kittson while the other had another mother.

It has been argued that William could be identified as one of these two sons. If the names Armour suggested are accepted, because Alexander and Robert were dead, the other son still alive and linked to the daughter would be John Henry. Fortunately, a tiny aspect of William's appearance remains to us. In the author's opinion, the daguerreotype of him which was published in Bain's 1901 
edition of Travels shows an individual whose physiognomy suggests "Indian" features. Furthermore, the younger Henry gives us a clue as to William's lineage. On 18 May 1814 , just before his death, the younger Henry wrote: "Quarrel between Mr. McT and H. [William Henry]. Orders from Fort William [produced] \&\&c. Poor $\mathrm{H}$. [William]. He fain would dispute his right with his Uncle, but there is too much brow beating." ${ }^{0}$ It may be asserted that the younger Henry may have been referring to himself in this entry, but Henry would not have confused an uncle with a cousin.

The identification is clear. ${ }^{\text {" }}$ The younger Henry identified Donald McTavish as William Henry's uncle. ${ }^{52}$ But, McTavish could only have been William's uncle under two scenarios. First, Henry the Elder may have had a relationship with McTavish's sister. This possibility can be discounted because it is known that McTavish came to Montreal from Scotland sometime around 1790, that no sister came with him and, at that time, Henry was married to Julia Kittson. The second scenario, which is given some credence by William Henry's appearance, would hold that the Elder had been married earlier, according to the custom of the country, to an Indian or mixed-blood woman who subsequently became the wife of Donald McTavish, or that he was married to a female relative of a woman who was McTavish's country wife.

Like Henry, there is no record of Donald McTavish having taken a country wife during the eighteen years he spent working in the Upper English River department of the North West Company. ${ }^{53}$ That he did, however, have "his own faults, equally common to all men" with regard to women and that he readily partook in the customs of the country are confirmed by his abandonment of Jane Barnes and his enthusiastic courting of Benjamin Clapp's Indian consort, Mrs. Clapp, shortly after his arrival at Fort George in 1813. ${ }^{54}$ Although the Elder Henry, in his Travels, gives no indication of having taken a country wife, the younger Henry's statement that Donald McTavish was William's uncle confirms that, in earlier years, the Elder did become involved with an Indian or mixed-blood woman who was 
related to Donald McTavish by marriage.ss Because all sources acknowledge that William was raised by Julia, it is logical to suggest that he must have been taken to Montreal by his father.

Acceptance of the younger Henry's testimony opens the door to certain explanatory comments on other unresolved family matters. At the end of his long adventure in Indian country, the Elder Henry seems to have formed an image of himself as a man of consequence. Before reentering familiar society, however, he may have decided to "turn off" his Indian (or mixed-blood) country wife for, it seems certain that she did not accompany him to Montreal when he returned there in 1776 . Henry may have chosen to remove William from his mother for the same reasons that had caused his former patron, Askin, to justify taking his three children away from their Indian mother and for transporting them from Michilimackinac to Detroit. ${ }^{56}$ Indeed, Askin's lifestyle at Michilimackinac in the early 1760s, demonstrates aspects which contribute to our understanding of the Henry household.

According to Quaife, as a result of Askin's involvement with an Indian woman, Manetre (or Monette), he had three children: Jolın Jr., Catherine, and Madelaine. Askin's relationship with this woman will not be dignified by calling it a country marriage. For most of his years, Askin was the owner of several Black and Indian slaves whom he used profitably in business. The mother of these children was an Indian slave who seems to have served her purpose and was, perhaps to assuage her anger at losing her children, manumitted by Askin on 9 September 1766. Unlike many southern slave-holders of that era, however, Askin

regarded the children as legally his own, and discharged for them the complete obligation of a tender and loving parent. All were educated, in so far as lay within his power, reared to civilization, and all contracted honorable marriage unions. ${ }^{57}$

Despite or because of his marriage on 21 June 1772 to Marie-Archange Barthe (a member of a prominent local 
Detroit family), with whom he had nine children, Askin raised these mixed-blood children in his frontier household. At Detroit, the children were brought up with little untoward effect, "occupying a family status identical with that enjoyed by the children born to Mrs. Askin." ${ }^{38}$ In this regard, it is interesting that Alexander Henry's recently purchased slave woman, Chopin, had a son baptized on 23 May $1763 .^{59}$ Alexander Henry, however, was not the father of record of that particular child since Mr. Du Jaunay, the missionary who performed the baptism, made it clear that the child was given the name Joseph and that "the father of the child was one la Mothe, a voyageur. ${ }^{\text {"60 }}$

One wonders, though, given the strong sense of familiarity with her new master which Chopin displayed, if this relationship involved far more than that of master/slave, if a son was the result of it, and if this son was given the name Robert. ${ }^{61}$ If this was the case, we could identify the dead midshipman, Robert, as possibly Henry's first born, not with Julia Kittson or with William's mother but with Chopin, his slave. ${ }^{62}$ Alternatively, the mother could have been William's mother or another Indian or mixed-blood woman. Certainly, in describing ChiefWawatam's approach to him in May 1763, offering presents in exchange for "adopting an Englishman, as his son, brother and friend," Henry gave an exact description of how trading relationships between incoming Europeans and Indians were cemented, except that Henry did not include a wife among the presents Wawatam Offered. ${ }^{63}$ Whoever was Robert's mother, there may have been more than a grain of truth in the rumour "that Robert Henry was the natural son of Alexander Henry by an Indian woman" and, based on Askin's example, Robert must have travelled to Montreal with Henry and William when they went there in $1776 .{ }^{64}$

During the early years, Detroit was a military frontier town and, like Michilimackinac, it was largely unaffected by strong anti-Indian sentiments. From his comfortable frontier home, Askin could rebuke Charles Patterson's cavalier treatment, upbraiding him for abandoning a child "that every body but yourself says is yours." ${ }^{55}$ Because of 
this attitude towards mixed-blood children, and after having been separated from their mother, Askin's children enjoyed what a loving and well-to-do father could offer his mixedblood children. However, at least one of these children would later show a significant trait, a selective application of racial bias which seems to have characterized many people of mixed-blood. John Askin Jr. became a fierce defender of his right to ownership of Black slaves. ${ }^{66}$

Perhaps before 1776, Henry had shared Askin's views on these matters and, when he returned to Montreal he had anticipated no problems in raising his mixed-blood sons in the same way that Askin had raised his children. But then Henry seems to have been caught in the throes of a lasting love for Julia Kittson and, like Marie-Archange Barthe, Julia Kittson seems to have welcomed Henry's two mixedblood sons into her new home. Despite outward appearances, however, for Julia, her own children, and for the Bethune/ Kittson clan, the presence of these sons may have been a constant, uncomfortable reminder of Henry's adventures during his less respectable days. Robert's early death may have offered a convenient means for Norman Bethune to avoid passing on the knowledge of Robert's existence to his and Margaret Kittson's children. Because William's existence was known to the children, however, and because he outlived most of the members of the Henry household, William was acknowledged as Henry's son and knowledge of him was handed down to Norman's own son, Norman William Bethune.

The Bethune words, however, reveal the emergence of another mixed-blood bias. While allowing William a place in the family record, the memorandum whitens him: it denies his non-European background and blinds historians to an important aspect of Henry's past. This condescending memorandum suggests that, after the death of Henry, Julia, and Norman, William's background was obscured by N.W. Bethune, the descendant of the Reverend John Bethune and Veronique Waddin, who like other Bechunes, may have been determined to throw off his part-Indian heritage 
in efforts to be fully accepted as a member of the upper echelons of the evolving sociery. ${ }^{67}$

This transubstantiation of racial biases visible in the Henry household was nor limited to Montreal. Indeed, Donald McTavish's example of easily abandoning women (and possibly children) in the country, seems to have been best emulated later by his relative, John George McTavish who, during the fall of 1806 , deserted his country wife at James Bay and "returned to Quebec, leaving a distressed Charlotte behind," more than likely with a parcel of children, as his subsequent treatment of Nancy McKenzie reveals. ${ }^{68}$ When removed from the pays en haut to areas such as Montreal or Detroit, the mixed-blood children of these country marriages, seem to have grown up ignorant of their maternal ancestry. William Henry, for example, may have known little of the other half of his ancestry until he had been in the western fur trade for some years. Having spent his early years in a more tolerant Montreal environment, perhaps sheltered and insulated by a caring father from the less tolerant aspects beginning to develop in the larger society, William Henry's recently gained knowledge, that his uncle, Donald McTavish, had earlier abandoned his relative(s), may have been the source of much discomfort.

Because of McTavish's superiority in the company structure at Fort George, in 1813 William would have had to have been not only deferential to him but also he would have had to stand by idly while McTavish, in the words of Henry, took "Mrs. Clapp in tow." Although the younger Henry does not give the reason for the quarrel between William and McTavish, it seems that, until the previous evening, Mrs. Clapp was the unnamed woman with whom William had been consorting for several days. William's anger at McTavish having expropriated his woman, may have been brought to an unhappy end by McTavish's production of the orders from Fort William appointing him as Governor. Given the hierarchical structure of the North West Company, McTavish's preeminent position would have established his right to take Mrs. Clapp away from William. The knowledge, however, that this McTavish 
was his uncle, one who may have abandoned his mother (or aunt) earlier, could have been the source of the "too much brow beating" at Astoria.

Although it has not been possible to establish the name of William's and Robert's mother(s), it is reasonable to suggest that these two Henry sons were mixed-blood and were older than John and Alexander. Henry's letters do not tell which of Julia's sons, John or Alexander, was the older but if Alexander was older than John, as the baptismal records suggest, and if John was alive after Alexander's death, as Henry's letter suggests, the question must be asked: why was Norman William Bethune unaware of John Henry and what eventually became of him? There is reason to believe that Norman Bethune knew all of Henry's sons, including John Henry and he may or may not have mentioned the name to N.W. Bethune because of the circumstances surrounding John's birth. These may have been further complicated by unpleasant events that occurred later in John's life. ${ }^{70}$ Although the idencity of John Henry is still shrouded in doubt, tentatively we may conclude our investigation of the "veil" surrounding the Henry household by suggesting that the names and the order of birth of Henry's children seem to have been: Robert, William, John, Julia, and lastly, Alexander. ${ }^{71}$

If these findings hold up to further scrutiny, historians are presented with a major difficulty in terms of three primary sources. The accuracy of the Bethune memorandum has been questioned throughout this paper and has been found wanting. Of the other two sources, either the Younger's journal is correct or the official baptismal records, which Armour used as verification, may have been inserted into the records of Christ Church after the fact. Since the younger Henry displayed an admirable frankness on all issues, including his involvement with Indian women and since, in their naming and in his will, he treated his mixedblood children with a greater degree of equality than the Elder Henry or the Bethunes, it seems more appropriate to accept the younger Henry's testimony over that of the baptismal records. 
But, if the younger Henry's testimony is correct, in the naming of his children, Alexander Henry purposely departed from the family's traditional naming pattern. Unlike the younger Henry, the elder could not allow the names John and Alexander to be handed down to his older mixed-blood children. Because those two names maintained the European, traditional, and social hierarchy, they were to be the preserve of children born to his European wife, Julia Kittson. Perhaps in this simple break with tradition, Alexander Henry revealed the seedling of the idea of "difference" as expressed in the bias of an imperial culture, a seedling that would grow and eventually overshadow, not only his household but, the historiography of the evolving society. The bosom of Henry's family may not have been as comfortable as Bain believed and, from the perspective of his mixed-blood children, Henry's circle of friends could not have been considered highly respectable.

Appendix I. The Early Genealogy of Alexander Henry, the Elder

Alexander Henry (1) m. Elizabeth (2)

d. 1744

John (3) James (5)

d. 9 Nov. 1766

d. 1744

m Jane (4)

d. 20 July 1778

(9)Alexander (the Elder) ${ }^{72}$

1739-1824

(11) John ${ }^{73} \quad$ (12)William ${ }^{74}$

m. Julia Kittson (10)

d. 1835

d. 1803

m. Mary Monteith (13)

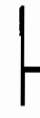

Alexander (6) William (7) Robert (8)

(14) William 75

b. 1783

d. 1864

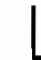

See Appendix II

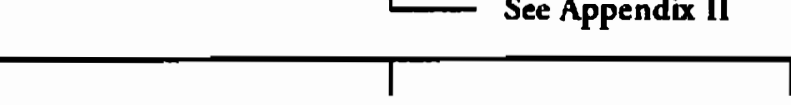


Appendix Il. The Genealogy of John Hernry (The Younger's Father)

(1 ) John Henry ${ }^{78}$ m. Mary Monteith(13)

d. 1803

(17) John ${ }^{79}$ (18)Alexander Younger ${ }^{\text {80 }}$ (19)James ${ }^{\text {31 }}$ (20)Robert
b. 1765?
b. 1778 ?
d. 1814
d. 1859

m.Christine

Bethune 1817

Lee Appendix III

(21)William (22)George $e^{92}$ (23)Samuel (24)Walter

Monteith

Appendix III. The Genealogy of Alexander Henry, the Younger

(18)Alexander (the Younger)

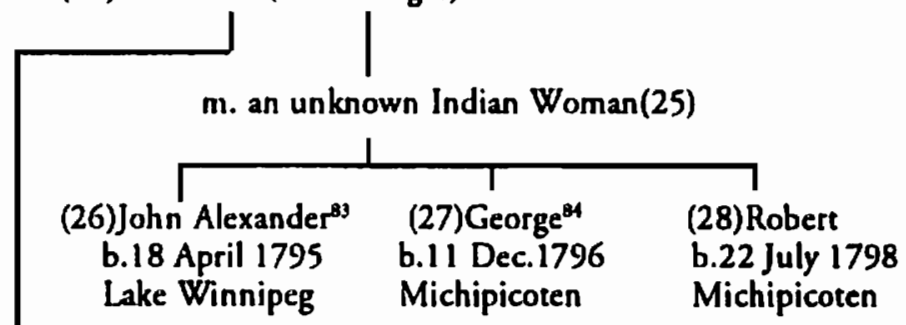

m. Daughter of "The Buffaloe" 1802(29)

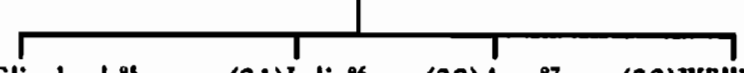

$\begin{array}{llll}\text { (30)Elizabeth } & \text { (31) Julia } & \text { (32)Ann } & \text { (33)William } \\ & \text { (39 }\end{array}$ 
Appendix IV. Suggested Genealogy for Alexander Henry the Elder

Alexander Henry m. Elizabeth

d. 1744

John James Alexander William
d. 9 Nov. 1766
m. Jane
d. 20 July 1778

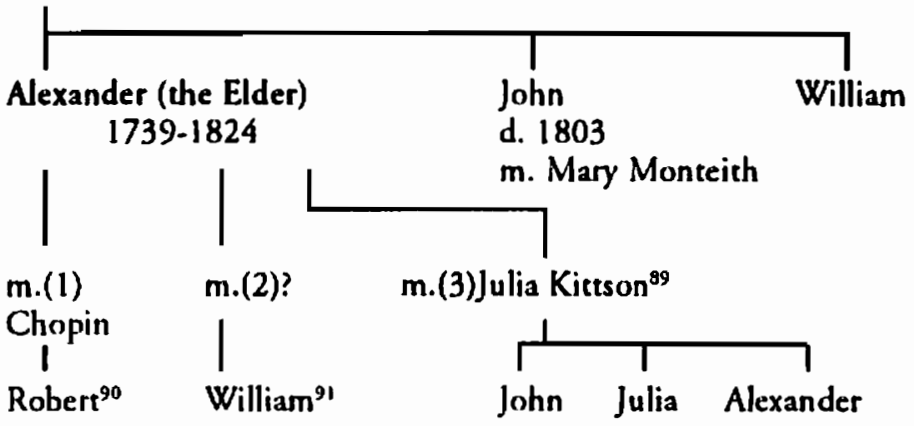

\section{NOTES}

'James Bain, ed., [Alcxander Henry, The Elder's] Travels and Adventures in Canada and the Indian Territories Between the Years 1760 and 1776, (Toronto: George N. Morang, [1809] 1966).

${ }^{2}$ See, for example: Franz Montgomery, “Alexander Mackenzie's Literary Assistant," Canadian Historical Review 18 (1937): 301-4; I.S. MacLaren, "Alexander Mackenzie and the Landscapes of Commerce," Studies in Canadian Literature 7 (1982): 141-50; also by the latter author, "Washington Irving's Problems with History and Romance in Astoria," The Canadian Review of American Studies 21 (1991): 25-51; and "Exploration/Travel Literature and the Evolution of the Author," International Journal of Canadian Studies/Revue internationaled'ttudes canadiennes 5 (1992): 39-68.

${ }^{3}$ Maclaren, "Exploration/T ravel Literature," 39-68, 40.

"Joseph "Tassé, "Memoir of Charles de Langlade," trans. Sarah Fairchild Dean. Wisconsin Historical Collections, 7 (1873): 123-87.

'John Thomas Lee, "Captain Jonathan Carver: Additional Data," in Wisconsin Historical Society. Proceedings, 1912: 103-4.

${ }^{6} \mathrm{Henry}$ Bedford-Jones and Milo M. Quaife, "That Myth Wawatam: A Symposium," Michigan History Magazine 7 (1923): 163-70.

'Freda F. Waldon, "Älexander Henry, esq., of Montreal, Fur Trader, Adventurer, and Man of Letters," MA thesis, Columbia University, 1930. 
${ }^{8}$ David A. Armour, "Alexander Henry," DCB, (Toronto: University of Toronto Press, 1987), 6: 316-9.

'lbid., 316.

'Barry M. Gough, ed., [Alexander Henry. The Younger's] The Joumal of Alexander Henry the Younger 1799-1814 (Toronto: The Champlain Society, 1988), 1: xix.

"Bain, Travels, xxiii.

${ }^{12}$ Armour, "Alexander Henry," 318.

"Chap. 3 of Anatol Scott. "The Legendary Veil: New Light on Alexander Henry, the Elder, 1739-1824." MA thesis, University of Alberta, 1994, argues that "the most that can be said about Alexander Henry, the Elder, is that ... he enjoyed a mediocre success compared to that attained by other celebrated fur traders of his day. That he did not accomplish more seems to have been the direct result of his absorbing need to be an independent operator, in charge of his own operation, and commanding his own patronage system. In an age which called for the curtailing of such business independence, when the necessity for combining forces with others was fashionable, by refusing to give up his independence. Henry became an anachronism. His inclination toward being a kind of 'freeman', whose ambitions did not allow him to take second place to any individual or Company, seems not to have endeared him to the most influential of his contemporaries," 49.

${ }^{14}$ The paper is a reworking of Ibid., 52-76.

isAccording to Waldon, Norman Bethune was married to Margaret Kittson who was the daughter of George Kittson (Julia Kittson's only son with her deceased husband, John George Kittson) and Anne Kittson, née Tucker. See Waldon, "Alexander Henry. esq," 45.

${ }^{16}$ According to Norman William Bethune, as recorded in an undated memorandum in the manuscript genealogies of the Bethune family which was, in 1930, in the possession of Mrs. Kenneth Bethune of Hamilton, Ontario; quoted in Ibid., 45-6. This information is to be considered as bordering on a primary source since it was almost firsthand, having been handed down to N.W. Bethune, directly from his father. Norman Bethune, and his mother, Margaret Kittson. In addition, N.W. Bethune was personally acquainted with Julia Kiteson, in that he reported: "(a)fter Mr. Henry's death in 1824 she lived with my mother who was her favorite grandchild and had been brought up by her. She died in our house in Montreal in 1835. I remember her well." (Ibid., 46).

'N.W. Bethune, in lbid.

${ }^{18}$ The first story was provided by Miss Mildred Kittson who, in 1930 , lived in Berthier-en-Haut, Quebec (lbid., 45). The second is based on Norman W. Bethune's memorandum (Ibid., 46).

19 It may be argued that the word "seems" is commonly used in Master's theses to avoid overstating one's argument. Nonetheless, its 
use was one of the clues which aroused my suspicion and which made it imperative that I pursue this investigation furcher.

${ }^{20}$ John E. Foster, "The Country-Born in the Red River Settlement: 1820-1850," PhD diss., University of Alberta, 1972; Jennifer Brown, "Company Men and Native Families: Fur Trade Social and Domestic Relations in Canada's Old Northwest," PhD diss., University of Chicago, 1976; Sylvia Van Kirk, "Many Tender Ties": Women in Fur Trade Society, 1670-1870 (Winnipeg: Watson \& Dwyer, 1980). Quote from Bain, ed., Travel, xxiv-xxv.

"Anna Jameson, Winter Studies and Summer Rambles in Canada (Toronto: McClelland \& Stewart, [1838] 1923), 116.

${ }^{22}$ Mary Hartwell Catherwood, The White Islander(New York: Century, 1893).

${ }^{23}$ Norman William Bethune, in a letter sent from Manchester, England, dated 27 January 1822, and addressed to Ann (Tucker) Kittson, who was later to become his mother-in-law. See Appendix C of Waldon, "Alexander Henry, esq," v.

${ }^{24}$ Marjorie Wilkins Campbell, The North West Company (Toronto: Douglas \& Mclntyre, 1983), 20.

${ }^{25}$ Alexander Henry to John Askin, in letters dated 27 August 1813 and 9 May 1815. See, respectively: Michigan History Magazine 32 (1903): 474-5; and Milo M. Quaife, ed., The John Askin Papers: 1747-1820. Burton Historical Records, 2 vols. (The Detroit Library Commission, 1928), 2: 782.

${ }^{26}$ Armour, "Alexander Henry," 318.

${ }^{27}$ In an earlier draft of his submission to the $D C B$, Armour had suggested that the couple had three sons, William. Alexander, and Charles. Armour later revised this information and provided exact dates for the births of the children Uulia (Oct. 22, 1780), Alexander (March 24, 1782), William (March 4, 1784), Robert (April 29, 1785), and John (Sept. 11, 1786)]. Apparently, the DCB was not provided with and has not since collected proof to support these assertions. However, Armour did indicate that the "source of this information is Archives nationales du Quebec in Montreal." (Correspondence between the $D C B$ and the author).

${ }^{29}$ Personal communication with David Armour and with the Archives Nationales du Québec.

${ }^{29}$ Because Robert was the brother of Alexander Henry, the Younger, he was the nephew of Alexander Henry, the Elder. In the absence of a record indicating that he had been adopted by the elder Henry, Bain's use of the term "adopted nephew" cannot be accepted. (Bain, Travels, xxxii; and Gough, Journah lxviii-lxxi.

${ }^{30}$ If the matriage took place in 1781, as Bain seems to have concluded based on cvidence from the Canadian Magazine, twenty-one years would have passed since her supposed 1760 arrival in Montreal. On the other hand, if Armour's $D C B$ entry is correct, the marriage did not 
take place until twenty-five years after her arrival. Armour's entry has been accepted as being the more valid since the registers of Christ Church also verify that "Mr. Alexander Henry \&e Mrs. Julia Ketson Widow were Married by Licence the 11 th June [1785]" [Registers of Christ Church (Anglican) of Montreal (ANQ-M, CEO601-0063)]. This documented information refutes Bain's assertion of a marriage which took place at about 1781 and casts doubt on the information provided by those who had informed the CM at the time of Henry's death. Although the $C M$ does not mention who were their informers, it is clear that Norman Bethune was the head of the Henry houschold and business at the time of his death.

"Waldon, "Alexander Henry, esq", 45.

${ }^{32}$ Waldon was much more influenced than Bain by the doubts which were a concern to Henry's Canadian Magazine biographer and which have continued to be concerns in the historiography. She retold the essence of the doubts he expressed in his introduction as follows: "The biographer must often look with doubtful idea on his sources of information. Sometimes material is to be found only with relatives or friends of the subject, who will often with praiseworthy charity wish to "throw a veil over his faults" and ascribe his action to the best motives" (Waldon, "Alexander Henry, esq," 30-1).

"lbid.. 10. Waldon suggests he was "probably of Scotch-Irish origin. "All available sources are silent on Henry's whereabouts during this period.

${ }^{35}$ The Archives Nationales du Québec document which records their marriage indicates that they were married by licence.

${ }^{36}$ In discussing the difficulty of unravelling the Henry farnily tree, Gough used the term "interlocking naming relationships" which became very instrumental in directing this work. In addition, the author would like to acknowledge the much appreciated role played by Gough as one of the referees of this paper. His suggestion that the rule of anonymity be broken and his subsequent provision of genealogical information on the Henry family also did much to substantiate much of my argument (Gough Journal, 1: xix). ${ }^{37}$ See Appendix I (Adapted from Gough, Joumah 1: xx).

${ }^{36}$ Letter: Alexander Henry to John Askin Michigan History Magazine 32 (1903): 474-5. Emphasis added.

"I Ibid. Emphases added.

${ }^{40}$ N.B.: It is recognized that the use of "I," under these circumstances, was common practice in these times when women and wives were not necessarily included in male discussions of children. The recognition of this bias is helpful but, if Henry was affected by it, it should be evident in his discussion of all the children. The difficulty here is that, in the same letter, Henry includes his wife when discussing Alexander but excludes her when discussing the other sons. This "mental" slip may be significant in that, unconsciously, it may be revealing important 
information about Henry, his other sons, and their relationship to his wife, Julia Kittson.

"William Stewart Wallace, ed., Documents Relating to the North West Company (Toronto: Champlain Society, 1934), 457.

${ }^{42}$ Alexander Henry to John Askin, in Askin Papers 2: 782.

${ }^{43}$ The author agrees with Waldon that this sentence is a good example of Henry's lack of litcrary ability and suggests that he must have had an extremely good editor or ghost writer working with him to produce Travels.

${ }^{4}$ Sec Appendix II.

"See Appendix III.

${ }^{46} \mathrm{All}$ sources, except N.W. Bethune and Armour, seem to agree that William was older than Alexander. The fact that William seems to have ventured into the northwestern fur trade before Alexander also supports the majority opinion.

17The argument which was presented earlier suggests that Henry links one of his unnamed sons to Julia in the words "only one son daughter."

${ }^{48}$ The sentence would read: "I have ... one son, [a] daughter, [and] one [other] son living; [of my other two sons], one was killed in the North West, the other died in the West Indies, [having been] a midshipman in the navy."

${ }^{49}$ To be discussed later.

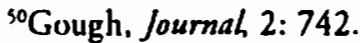

"Scott, "The Legendary Veil," 91-8, suggests that the Younger Henry's journal seems to have been brought to Montreal by Angus Bethune, in 1815, and kept in the elder Henry's household, where Norman Bethune, in attempting to edit it for publication, may have removed unacceptable portions of it. However, Norman's attempts at editing the journal may have proven to be unsuccessful. Subsequently, he seems to have brought George Coventry from London to act as ghost writer, a task which Coventry seems not to have relished, and which, for ethical reasons, he seems to have abandoned.

52In his editing of the Younger's Journal, Coues makes this Mr. McT into Mr. D. McTavish. (See Elliott Coues, ed., [Alexander Henry, The Younger's] New Light on the Early History of the Greater Northwest: The Manuscript Journals of Alexander Henry, Fur Trader of the Northwest Company, and of David Thompson (Minneapolis: Ross \& Haines, [1897] 1965). In The Journal of Alexander Henry the Younger 1799. 1814, this Mr. McT can be confused for John George McTavish, a mistake which is evident in Scott, "The Legendary Veil." Despite its valuable contribution to the historiography, the Gough edition also seems to confuse James Chisholm McTavish (see Coues, New Light, 2: 894 notes 8 and 9) with John George McTavish. The latter having departed Fort George on 4 April 1814, can no longer be reported as having been present there after that date. 
33Jean Morrison, "Donald Mc'Tavish," DCB (Toronto: University of Toronto Press, 1983), 5: 559-69.

${ }^{54}$ Gough, Journal 740-4; quote from p. 740.

"See Scott, "The Legendary Veil," 94. The suggestion is made here that, during the period, 17 May 1811 to 15 November 1813 , it seems likely that "the Younger and William Henry discovered the identity of William's mother and that information may have been recorded in the journal." Therefore, in 1815, when the journal was brought to Montreal it may have posed many difficulties for William's father. Having acknowledged Travels earlier, having accepted an idealized characterization, and having taken pains to not admit his involvements with Indian women, the elder Henry would have experienced considerable unease when he discovered the existence of this type of compromising information in the Younger's journal.

${ }^{36} \mathrm{I}$ have argued that Henry was involved in client-patron relationships with John Askin, William Johnson, and John Jacob Astor but "on each occasion he abused the opportunities which had been given him because of his insistence on independence, which can only be explained in light of his having had too high an opinion of himself." See Anatol Scott, "The Legendary Veil," 50.

"Quaife, Askin Papers, 1: 13.

${ }^{38}$ See David R. Farrell, "John Askin," DCB, 5: 37-9, 39. Quote from Quaife, Askin Papers, 1: 14.

${ }^{99}$ Wisconsin Historical Collections 19 (1910): 67. Golbid.

${ }^{61}$ When Chopin offered her child for baptism, her reaction to Mr. Du Jaunay's suggestion that she too be baptized is indicative of a person with a high degree of self-esteem, the result, perhaps, of having formed an accepted and meaningful relationship with a prominent trader. Chopin protested that "she had never had any other faith than that of the holy Catholic, Apostolic and Roman Church and that her new master had promised her never to force her with regard to her Religious belief" (Ibid).

${ }^{62} \mathrm{An}$ objection that this son could have been named John instead of Robert could be raised here especially since, on the surface, it would suggest that Henry may have continued the naming tradition. This possibility was entertained but, for it to be valid, Alexander would have had to have been Henry's second son and his mother someone other than Julia. Henry's letters, the Bethune memorandum and Armour all deny these possibilities. The evidence suggests, therefore, that William was the second son and that John, who is linked to his sister, Julia, was the third.

${ }^{63}$ See Bain, Travels, 73-6.

${ }^{6}$ Quoted from Mary Larratt Smith, Prologue to Norman: The Canadian Bethunes (Ottawa: Mosaic Press, 1976), 19. Mary Smith is a member of the Bethune family and, although she was referring here to the 
Robert Henry who was the brother of Alexander Henry, the Younger, over time the rumour mill may have become confused over the two Roberts.

"65arrell, "John Askin," 5: 37-9, 39.

${ }^{6}$ See his letter to his father in Quaife, Askin Papers, 2: 772.

${ }^{67}$ See Anatol Scott, "The Legendary Veil," 77-105. At about this time, the Bethunes seem to have removed from their genealogy all references to Jean Etienne Waddin. Perhaps this was the means chosen by the descendants of Reverend John Bethune to rid the family of the taint left by Waddin's disreputable behaviour, that of having had different families in Montreal, England, and the Indian country. Thus, with the able assistance of Professor A.H. Young and based on the words of Beatrice Bethune, Véronique Waddin, Jean's Montreal daughter who, in 1782, became the wife of the Bethune family patriarch, would undergo an official genealogical transformation by 1933. She would thenceforth become the daughter of a Swiss professor. Wadden, of New York. But long before this transformation, Norman William Bethune and generations of other Bethunes had developed a distinct bias toward anything Indian in their background. Thus, Angus Bethune, the first of the Bethune children, was virtually removed from the family memory and his mixed-blood wife, Louisa McKenzie, would be referred to by those Bethunes who remembered her as "Miss Green Blanket." This information is to be found in the informative work of a Bethune, Mary Larratt Smith.

${ }^{68}$ Sylvia Van Kirk, "John George McTavish," $D C B$ (Toronto: University of Toronto Press, 1988), 7: 577-8. Quote from 578.

${ }^{69}$ Gough, Journah 578.

${ }^{70}$ Because of limitations of space, after considering the criticisms of an anonymous referee and at the suggestion of the editors, the author has agreed to defer further comment on John Henry pending further research.

${ }^{71}$ See Appendix IV.

${ }^{72}$ As the first son, he is named after \#1, his grandfather.

${ }^{73}$ As the second son, he is named after \#3, his father.

${ }^{74} \mathrm{He}$ is named after \#7, his uncle.

${ }^{73}$ Based on the three foregoing footnotes, if this was the first son and if there was a traditional naming pattern, the name should have been John, after \#3, his grandfather.

${ }^{76}$ As the second son, Alexander would have been the likely name since he would have been named after his father, $\$ 9$, Alexander Henry, the Elder.

"Named after her mother, \#10, Julia Kittson.

${ }^{7}$ As second son. he is named after his father, $\# 3$ of Appendix I.

${ }^{7}$ As the first son of \#11, he is named after his grandfather, \#3 of Appendix I. 
${ }^{80}$ As the second son of \#11, he could not be given the same name as the first son and the father. He was therefore named after his oldest uncle, \#9 of Appendix 1 .

"Note that this son as well as \#s 20 and 21 have all been named after Henry uncles of the father's choice.

${ }^{82}$ Named after George Kittson or, he and the following two sons, numbers $23 \& 24$, may have been named after members of Mary Monteith's, \#13, family. Given the preference which the younger Henry later gave to the naming of children after the Kittsons, this child may have been named after George Kittson.

${ }^{83}$ This first son is named after his grandfather and his father but, the hierarchy is maintained; the name John is given first place, after the grandfather, \#11, while the name Alexander, after the father, \#18, comes second.

MThe grandfather and father having been honoured, the second and third sons are named after uncles, \#20 and 22 . The name George may have been given precedence in honour of George Kittson.

${ }^{9}$ 'As the first daughter, she was named after the female founding member of the family, her great-great grandmother, $\$ 2$ of Appendix I. ${ }^{86}$ The younger Henry may not have had much of an attachment to his grandmother, Jane, or to his mother, Mary, since they were passed over and Julia Kittson seems to have been given preference in the naming of his second daughter and, later, in his Will.

${ }^{87} \mathrm{His}$ third daughter seems to have been named after Ann Tucker, George Kittson's wife.

${ }^{88} \mathrm{His}$ last son is named after $\# 21$, the child's uncle.

"9oulia Kittson was Irish and was married to Henry. Although the exact year of their marriage is in dispute, there seems to be little reason to doubt that, in the naming of their children, the Henry family tradition is continued: John is named after his grandfather, Alexander is named after his father, and Julia is named after her mother.

${ }^{90}$ If Chopin was the mother of Robert, this would have been a country marriage. The suggestion is that because Henry may not have viewed this type of marriage in the same way as he may have that with a European woman, he could not allow this son to carry the name, John, which family precedence dictated.

${ }^{91}$ As per the previous footnote, because this was also a country marriage, the name which family precedence dictated. Alexander, could not be given to this son. 